\title{
Review \\ 3D Printing in Drug Delivery and Biomedical Applications: A State-of-the-Art Review
}

\author{
Muhammad Arif Mahmood 1,2 (D) \\ 1 Laser Department, National Institute for Laser, Plasma and Radiation Physics (INFLPR), \\ 077125 Magurele, Romania; arif.mahmood@inflpr.ro; Tel.: +40-21-4574550 \\ 2 Faculty of Physics, University of Bucharest, 077125 Magurele, Romania
}

check for updates

Citation: Mahmood, M.A. 3D Printing in Drug Delivery and Biomedical Applications: A State-of-the-Art Review. Compounds 2021, 1, 94-115. https://doi.org/ 10.3390/compounds1030009

Received: 14 July 2021

Accepted: 15 September 2021

Published: 24 September 2021

Publisher's Note: MDPI stays neutral with regard to jurisdictional claims in published maps and institutional affiliations.

Copyright: (C) 2021 by the author. Licensee MDPI, Basel, Switzerland. This article is an open access article distributed under the terms and conditions of the Creative Commons Attribution (CC BY) license (https:/ / creativecommons.org/licenses/by/ $4.0 /)$.

\begin{abstract}
Personalized medicines are gaining popularity day by day as they empower patient genomics and assist in improved drug design with minimum side effects. Various dosages can be combined into one dose that fits the patient's requirements. For this purpose, 3D printing is a new technology to produce medicine based on patient needs. It utilizes controlled devices to prepare active pharmaceutical ingredients (API) in a layer-wise fashion to develop an appropriate tailored drug transport structure. It contains numerous methods, including inkjet printing and fused deposition modeling. For this purpose, scientists have used various materials, including polyvinyl alcohol, polylactic acid and polycaprolactone. These materials have been applied to design and develop forms that are suitable for tuning the drug release. Different forms of dosages, including tablets (immediate and pulsatile release) and transdermic dosages, can be produced using the 3D printing technique. Furthermore, the 3D printing technique can also be used to prepare customized medicines to treat life-threatening diseases. In the case of patients needing various medicines, a 3D printer can be used to design and manufacture only one dosage incorporating different medicines. This article reviewed 3D printing utilization for customized medicines based on one's needs. Various methods and materials used in medicine 3D printing were discussed with their applications.
\end{abstract}

Keywords: 3D printing; drug delivery; polymers; personalized drug delivery system; biomedical applications

\section{Significance of Personalized Medicines (PM)}

The drug market has recently observed a profound revolution and development in patient therapy that delivers effective and harmless medications. Personalized medicine (PM) has seen renowned growth. It can offer maximum protection boundaries, which lessen the after-effects and guarantees improved patient safety [1,2]. PM seeks to provide a unique opportunity that attempts to change patient biology through medication preferences, dosages and treatments. Its goals are to provide improved health care facilities, simplify research, and discover diagnostics and remedies [3,4]. In 1997, to treat breast cancer, Herceptin was rejected in Phase-III patient trials as the medicine was found futile for all inhabitants. Still, after careful review, women who tested positive for HER2 exhibited a significantly improved response. In 1998, the food and drug administration, USA, offered medical experimental data for HER2-positive patients and permitted the drug [5]. In Europe, the Vectibix drug was unapproved by controllers because it could not be used for various patients [6]. This drug was supposed to treat Amgen colon cancer. The corporation completed an overall data assessment and exposed that Vectibix can perform well in the victims with tumor-lacked KRAS gene mutation, and the drug was allowed for such patients only [7].

Therefore, a physician can look into a patient's gene variation profile, pick a medicine and suggest a treatment that decreases after-effects, thus yielding positive consequences. The individual vulnerability to specific diseases could be identified before manifestation. Hence, PM can be utilized to stop infections in vulnerable persons. With PM assistance, 
doctors can go for a one-size-fits-all model to prescribe medicines for an individual patient. Due to patient hereditary dissimilarities, gene reactions for specific drugs could differ from person to person. Hence, PM has propagated a unique discipline named "pharmacogenomics" that identifies an appropriate gene affecting medicine $[1,2,8]$. Scientists are exploring different strategies to develop personalized medicine, one of which is 3D printing. This article conducts a detailed analysis of 3D printing in drug delivery.

\section{Three-Dimensional (3D) Printing}

3D printing produces 3D parts in a layer-wise fashion using computer-aided (CAD) designs [9-15]. In 1996, for the very 1st time, 3D printing was used to prepare tablets [16]. Personalized 3D printed drugs can resolve various issues related to patients, including pharmacogenetic polymorphism [17]. Patients can also access more effective drugs with the least exposure to adverse drug reactions, which can elevate patients' survival proportion [18-20]. 3D printers can produce various unique medicines, including transdermic patches and tablets. They also can produce a single dose containing various drugs to treat multiple diseases designed at the treatment point. It enhances patient compliance with the minimum side effects, resulting in a radical change in medicine design [21]. 3D printing technique has enormous characteristics and versatilities, producing any dose for various applications [22-26]. This method utilizes numerous health care facilities ranging from public drugstores to hospitals. Administration in these areas can increase medicine availability and decrease medicine consumption. Medication can be rapidly manufactured by using 3D printers in disaster zones, emergency sections, quick response units, and military missions [27]. 3D printing of reduced reaction vessels to synthesize API, on request, can deliver additional flexure to researchers and scientists. In comparison with traditional techniques, 3D printing can synthesize a wide variety of molecules at a mini scale, predominantly useful for those with elevated cost or deprived steadiness [28]. Clinical trials demand a vast range of doses [29].

Owing to the flexibility in the 3D printing process, a vast range of medications can be produced to identify optimal product growth without enhancing the lead time or production cost. Hence, lives are protected at the lowest cost deprived of treatment delay. 3D printing reduces the medicines' side effects and allows patients to take more benefits [30]. 3D printing can quickly produce several dosages by varying densities, diffusivities, internal geometries, and drug components. It also resolves the drug transfer issues; however, the process has a few limitations, including solvent mismatch and heat resistivity of the printed substantial. To resolve such issues, development in the 3D printing process is mandatory to effectively combine it with a novel medicine transport structure [31]. For financial and rational benefits, 3D printers can also be used in hospital drugstores to produce individual medication. Patients usually spend a huge amount of money on standard medicine that can or cannot cure patients. On the other hand, 3D printed personalized medicines can introduce an advanced step treatment by introducing low-price medications that can cure the illness. For a patient, the health record data can also be provided to any health care practitioners via digitalized means. However, to guarantee this intervention success, a welldefined software database is desirable to ensure patient data security and profile [32]. For this objective, the links among software and high-tech developers, doctors and regulatory representatives must uphold monotony throughout the world.

3D printers can be handled easily with accurate material printing after changing the number of active ingredients. An accurate dosage with an anticipated design can be obtained that is not easy via other processing techniques [33]. The 3D printing technique can also produce even orphan drugs. These drugs are costly and, within Europe, affect 1 in 2000 people [34]. 3D printing has developed certain advantages, such as low-cost printing, wide availability, approved pharmaceutical ingredients, a substantial enhancement in morphology and mechanical confrontation, the appropriateness of various drug molecules, and the absence of post-printing steps [35]. 


\subsection{D Printing: Steps to Follow}

In 3D printing, medicines, parts, medical implants, and devices are produced by accumulating material in a layer-wise fashion until the desired CAD file is obtained, physically [36]. Today, several printing processes are available with diverse printing techniques; however, each technique involves the following steps [13,37,38]:

I. CAD software is applied to develop a three-dimensional model.

II. Here, the model developed in step I is transformed into ".STL" format.

III. Following on, the file is sliced via slicer (software).

IV. A 3D part is manufactured via Computer Numerical Control codes.

Based on the utilized technique, powder grains, fibers and binding mixtures can be used to endorse the printing. The desired medicines can be achieved by mixing and printing the feedstock. Following on, the printed shapes are processed through secondary manufacturing methods. The unprinted material is harvested and recycled [39]. Quality by design system is generally utilized in the drugs design and manufacturing industry. Initially, the medicine and filling agents are used to prepare the feedstock. Subsequently, sintering, refining and packing are used [37]. In the last 15 years, 3D printing technology usage has increased in the healthcare sector and pharmaceutical industry. From research and development to patient treatment, this technique plays a significant part.

\subsection{Inkjet Printing (IP)}

IP is a low-temperature and pressure method that includes the material printing in liquid form or dense heterogeneous composition. This process is suitable for a wide range of materials, including polymers, nanomaterials and dielectrics. In this technique, the material to be printed is extruded via a mini nozzle in the printing head, which moves over a given surface, resulting in multi-layers formation [40]. IP technology can be classified into (a) continuous-jet printing $(\mathrm{CP})$ and (b) drop-on-demand printing (DP). These types have been attained based on the droplet generation method.

\subsubsection{Continuous-Jet Printing (CP)}

$\mathrm{CP}$ depends on a forced material flow to generate a charged precipitation, thus producing a nonstop stream. In the setup, the electro-static side plates gauge the droplets to the base plate, depositing the material. During the process, the waste material is also recycled so that it can be further utilized [41]. CP and DP have thermal or piezo-electric printing heads that can monitor the material viscidness and produced drop properties [42].

\subsubsection{Drop-on-Demand Printing (DP)}

DP printing, containing 1000 nozzles, has a particular and shorter extravagant execution. Thermal and piezoelectric mechanisms primarily trigger these printheads. The electric current (EC) induction generates heat in the printing head, leading to bubble formation in the evaporative material. It mobilizes a small volume of liquid from the nozzle due to drop formation. The thermal IP involves the high vapor pressure solvents and results in elevated temperature, resulting in deprivation of organic compounds [43]. Furthermore, piezoelectric printing heads are used for piezoelectric materials that inflate and shrink when EC is provided [44]. This variation can give sufficient pressure to expel a droplet owing to the pulse development, thus making a fluid shear rate around 105/s [36,42]. The two printing systems explained above are illustrated in Figure 1. 


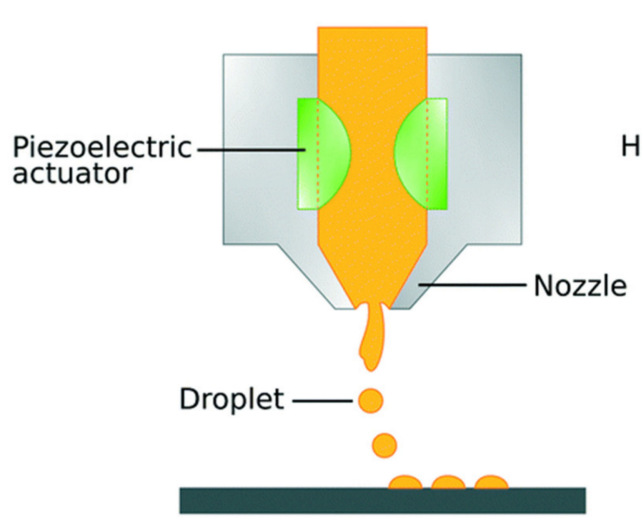

(a)

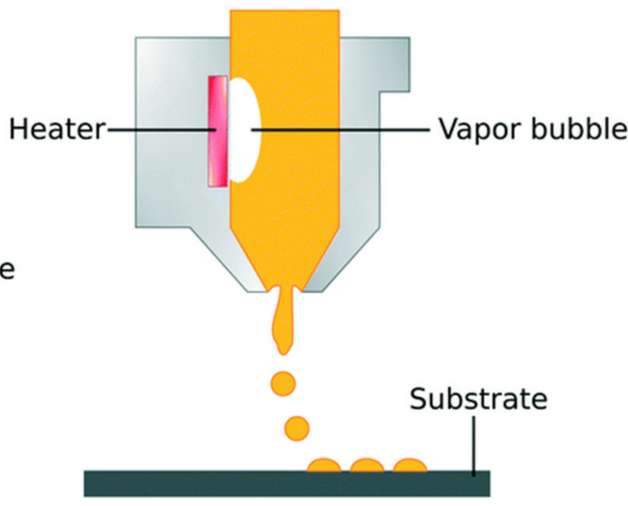

(b)

Figure 1. Drop-on-demand inkjet printing process (DP): (a) piezo-electric DP and (b) thermal DP [45]; published under an open-access license by the Royal Society of Chemistry.

When the formulated layers are deposited in a layer-wise fashion and material solidification occurs, identified as drop-on-drop printing, the printer head accumulates the droplet at the top of the solidified material defined as drop-on-solid printing [46], as shown in Table 1. Various accumulations are achieved simultaneously using diversified ingredients and colors $[47,48]$.

Table 1. Difference between drop-on-drop and drop-on-solid printings [47,48].

\begin{tabular}{ll}
\hline \multicolumn{1}{c}{ Drop on Drop Printing } & \multicolumn{1}{c}{ Drop on Solid Printing } \\
\hline $\begin{array}{l}\text { Solid layer printed by droplets using a } \\
\text { binding material. } \\
\text { Droplet magnitude, binder type and } \\
\text { solidifying rate influence the } \\
\text { final product. }\end{array}$ & $\begin{array}{l}\text { Binding of material with an elevated melting } \\
\text { point with the low melting point binder, } \\
\text { resulting in droplets generation. } \\
\text { The process is influenced by powder } \\
\text { po licensed application. } \\
\text { It is possible to conduct a lot of } \\
\text { drug loading. }\end{array}$ \\
The process is challenging to implement. & $\begin{array}{l}\text { density, biner wettability, and reactivity. } \\
\text { "TheriFrom" license is granted. } \\
\text { Controlled medication administration in a } \\
\text { variety of sizes is possible. } \\
\text { Its use may be limited due to low drug loading. }\end{array}$ \\
\hline
\end{tabular}

\subsection{Fused Deposition Modelling (FDM)}

FDM printing process is prevalent and low-cost, and it utilizes a printed head same as IP. Contrary to IP, heated plastic drops are ejected from the printing head as it translates, thus accumulating thin layers [49]. In FDM, thermoplastic materials are usually used [50,51]. Figure 2 shows the schematic of the FDM process. To begin, materials in the melted form are passed using a nozzle and printed in the layer form, thus generating filaments, which hardened after solidification. The printing characteristics are primarily dependent on nozzle size, material dropping pressure and feeding rate. 


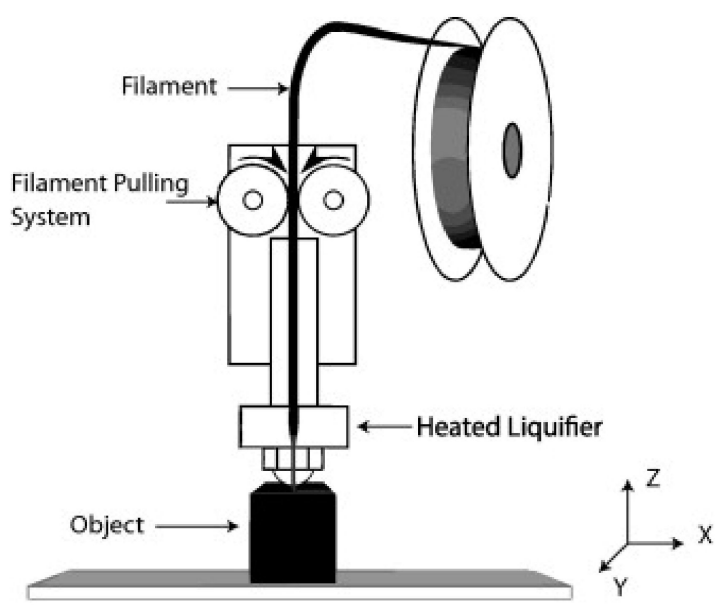

Figure 2. Schematic illustration of Fused Deposition Modelling (FDM) [52]; published under openaccess license by Elsevier.

FDM benefits over laser powder bed fusion printing are:

- It can accurately manufacture complex supports.

- It produces parts with decent mechanical strength, 3D model design, and formulation

Surface area. ents and restricted material restrain its utilization [52].

\subsection{Stereolithography (SLA)}

SLA is entirely based on the photopolymerization theory. Following the interaction of the photo-initiator with UV light, free radicals are produced [35]. Figure 3 exhibits the SLA schematic.

\section{(a)}

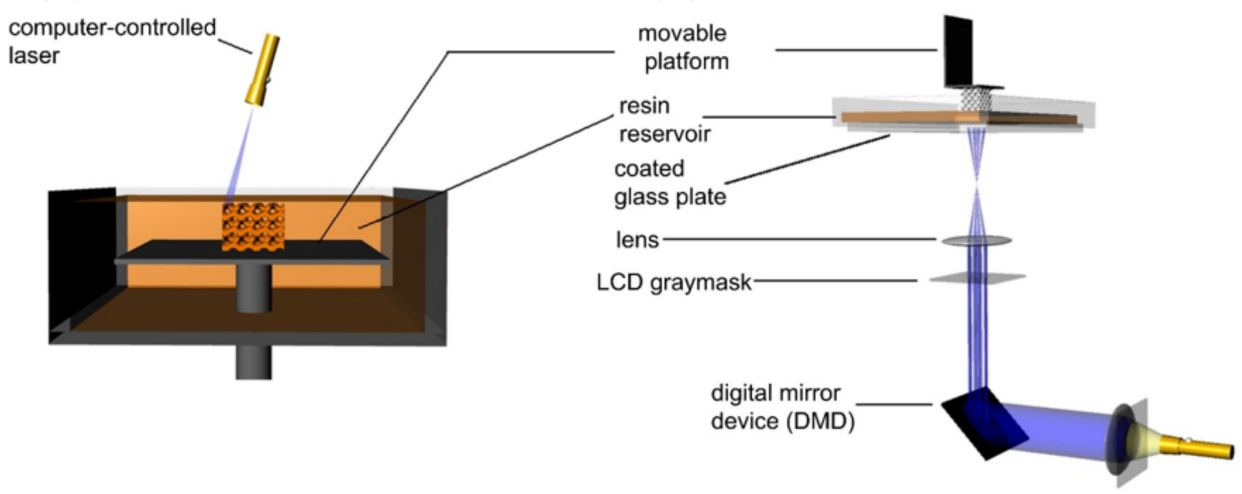

Figure 3. SLA setups: (a) by a laser used for scanning, and (b) by analog light prognosis [53]; published under open-access license by Elsevier.

By manifesting the photosensitive liquid resin to the ultraviolet (UV) laser, materials' particular areas experience localized polymerization [54]. In SLA, UV light is allowed to move in a direction perpendicular to the liquified resin surface. After exposure, when a given deposit is solidified, another liquid resin layer is placed. This process continues until an end product is achieved in finished form. When a given product is completed, an extra amount of resin is pumped off and can be reused later. The final product is cleaned to eliminate an extra amount of resin. Following on, the support assemblies are detached. Generally, the printed part has a few rough appearances same as the casted parts that are further refined using coating $[55,56]$. The laser-based manufacturing is primarily demanding for numerous reasons: (a) part manufacturing at high resolution, (b) better 
surface finish with no need of post-processing, (c) better $z$-axis growth due to optimum bonding among the printed layers, and (d) less time requirement compared to traditional methods [57]. The critical parameter in the SLA printing is the cured layer thickness, which depends on the provided light energy [53].

\subsection{Extrusion Based Bioprinting}

This method uses a machine- or pneumatically-driven pressure to distribute bio-ink via an outlet and obeys a computer-designed model [58]. This process also involves printing in a layer-wise fashion same as other printing methods. Bio-inks are usually organic materials. This technique permits precise cells printing with minimal cells impairment. The printing technique is shown in Figure 4.

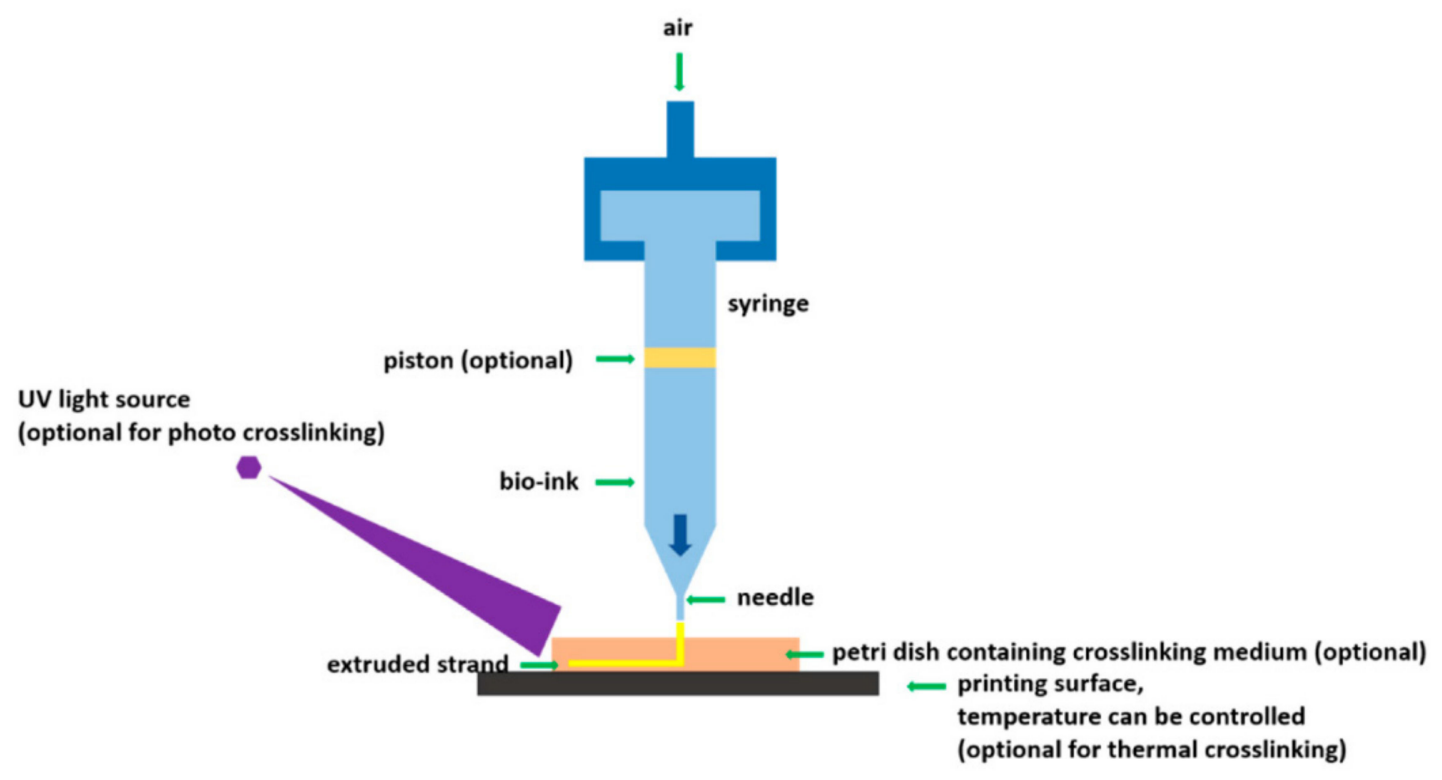

Figure 4. Schematic of extrusion-based bioprinting [59]; under an open-access license by MDPI.

Pneumatically controlled set-ups are linked with distribution delays as they need air in a compressed state. On the other side, they are highly effective for materials with high viscosity. However, the piston-controlled printing usually offers a straightforward command on the nozzle's hydrogel stream. Contrariwise, set-ups involving screws deliver an elevated three-dimensional dominance and are recommended for hydrogels with high viscosity $[60,61]$. By using this method, the cells can be printed and distributed accurately, thus increasing the printing process. This is why organic scaffolds are made by this method. On the other hand, the printing speed is comparatively high and desirable models can be reached [62]. So far, this process has been applied in bone repairing [63], heart valves [64], tissues [65], muscles [66], and neurology [67]. In this process, substantial choice and toughness remain a significant problem. The researchers are resolving these issues by adding sacrificial constituents in the bioprinting process [68]. Table 2 collects the pros and cons of various 3D printing technologies. 
Table 2. Pros and cons of printing technologies mentioned above.

\begin{tabular}{|c|c|c|c|}
\hline 3D Printing Technology & Pros & Cons & References \\
\hline Inkjet printing. & $\begin{array}{l}\text { By accumulating a small } \\
\text { volume, high three-dimensional } \\
\text { resolution can be achieved. }\end{array}$ & $\begin{array}{l}\text { A drying phase is required. } \\
\text { - The printing period is high. }\end{array}$ & {$[69,70]$} \\
\hline Fused Deposition Modelling. & $\begin{array}{l}\text { - } \quad \text { Easily accessible. } \\
\text { - } \quad \text { Maintain a high level } \\
\text { of consistency. } \\
\text { - No post-printing solidification } \\
\text { is required. } \\
\text { The product is mechanically } \\
\text { robust and has a low degree } \\
\text { of friability. }\end{array}$ & $\begin{array}{l}\text { - } \\
\text { Theeds advance filaments } \\
\text { temperatures damages the } \\
\text { active chemical. } \\
\text { Depending on nozzle } \\
\text { magnitude, a low-resolution } \\
\text { control is needed. }\end{array}$ & {$[31,71-73]$} \\
\hline Stereolithography. & $\begin{array}{l}\text { - High resolution and accuracy. } \\
\text { Capable of producing objects } \\
\text { and layers that are submicron } \\
\text { in size. }\end{array}$ & $\begin{array}{l}\text { - Curing is required after } \\
\text { deposition. } \\
\text { An inadequate resins' numbers } \\
\text { are presented. } \\
\text { A residual investigation is } \\
\text { required for pharmaceutical } \\
\text { usage. } \\
\text { High resolution takes a } \\
\text { prolonged printing time. }\end{array}$ & {$[74,75]$} \\
\hline Extrusion-based bioprinting. & $\begin{array}{l}\text { A high amount of drug loading } \\
\text { can be carried out. } \\
\text { Multiple releases modes can be } \\
\text { produced in a sole tablet. }\end{array}$ & $\begin{array}{l}\text { Depending on nozzle } \\
\text { magnitude, a low-resolution } \\
\text { control is needed. } \\
\text { Drying is needed after } \\
\text { solidification. } \\
\text { Medicine characteristics include } \\
\text { high flimsiness. } \\
\text { Regulate the material's flow via } \\
\text { nozzle is difficult to achieve. }\end{array}$ & {$[18,76,77]$} \\
\hline
\end{tabular}

\section{3D Printing for Drugs Development: Early Phase Drugs, Complex Drugs, Unique Drugs, Solid Oral Drugs, and Polymeric Drugs}

Various tailored dose forms can be achieved using 3D printing, taking into account unique release ratios and contraptions. Capsules named "Chronocaps," a modern design has been produced using a 3D printing process based on pulsatile drug transport structure [78].

Melochhi et al. [79] examined the performance difference between injection molded and 3D printed capsule designs. According to the study, the drug showed a lag period before it passed on to the market. This brought relief for a long time; however, compared with the injection molding process, similarities were found in terms of morphological properties. The conclusion is that $3 \mathrm{D}$ printing can be used as an alternative to injection molding technology. The immediate release dosage form dissolves and releases the drug quickly. Formulations with hydrophilic polymers, povidone, hydroxypropyl cellulose, hydroxypropyl methylcellulose and graft polymers were used as polymers. Okwuosa et al. [80] used various ratios of PVP as the polymer, triethyl citrate as the plasticizer and talc as the filler, and prepared instant release medicines. It was analyzed that more than $90 \%$ of the drug dissolves rapidly under a $10 \%$ applied load, thus highlighting the 3D printing benefits.

The FDM instant release medicines were produced by mixing 5-Aminosalicylic and 4- Aminosalicylic acids. Polyvinyl alcohol, which is readily available, was used to load the drugs. For 5aminosalicylate and 4-aminosalicylate, the filament drug loading was 
$0.06 \mathrm{w} / \mathrm{w}(\%)$ and $0.25 \mathrm{w} / \mathrm{w}(\%)$, respectively. The tablets printed with $90 \%$ infill showed $100 \%$ release after $4 \mathrm{~h}$, demonstrating that the process is a successful and cost-effective production technique. 4-Aminosalicylic acid, on the other hand, showed slight heat deprivation, representing that it is insufficient for thermolabile medicines [72].

Khaled et al. [18] linked a self-made bi-layer guaifenesin medicine produced by 3D printing to a commercialized Mucinex medicine. The instant release and sustained release layers were utilized to generate the bi-layer. Guifenasin powder, HPMC 2910 as a binder, microcrystalline cellulose, and sodium starch glycolate made up the instant release layer. Hepta-propyl methylcellulose and polyacrylic acid were found in the sustained release layer. The medicine containing $14 \mathrm{w} / \mathrm{w}$ (\%) Hepta-propyl methylcellulose and 2\% binding material liquified quicker than Mucinex. The disintegration rate also reduced as Hepta-propyl methylcellulose was applied. Yu et al. [81] used 3D printing to generate a fast-decaying medicine, containing loose powder. The internal powder section was drawn inevitably and accumulated the binding material at the designated regime, layer-wise. The fragmentation and wetting periods were $22 \mathrm{~s}$ and $52 \mathrm{~s}$, respectively. There are numerous ways to transport medicines via skin capillary, including transdermic patches and infusion accompaniments [82]. The 3D Printing process has been utilized to manufacture blotches and micro-needles. In 1970, transdermic medicine transport gained universal consideration when a "scopolamine" blotch was developed [83]. The blotch was modelled to have various films providing constant comfort for a longer time. Two various approaches were implemented for blotch modelling. A reservoir blotch with a section, where the medicine can be kept, can control the drug transport. It was achieved to gain steady release kinetics; though, overdose was also informed due to the faulty membranes [84]. Furthermore, the matrix form blotch was also manufactured to resolve the problem of reservoir type blotch. They usually have matrixes responsible for drug release into the skin [85]. Difference types of blotches, including Emsam [86], EvraTM [87] and Exelon [88], are available in the market.

Besides avoiding the hepatic first-pass metabolism, micro-needles also avoid the stratum corneum. The micro-sized perforated devices disrupt the outmost coat, thus attaining the microcirculation [80]. In 2012, Innoture Ltd. published a patent. In this patent, micro-needles were formed by multi-layers printing, one after another, thus giving solid micro-needles. Innoture Ltd. used drop-on-solid and drop-on-deposition techniques to achieve mini-implants. A micro-needle blotch named "Radara" was developed that can be utilized for dermatological causes to transport hyaluronic antitoxin to surge epidemical hydration quantity [89].

Boehm et al. [90-92] used stereolithography to prepare micro-molds, capable of producing micro-needles for various analyses and disease cures. Micro-needle can be straight-forwardly printed via stereolithography, and, then, a coating can be applied. Gittard et al. [93] manufactured micro-needles using acrylate polymers. These needles were primarily intended for wound curing. The silver + zinc oxide layer was deposited via the laser-deposition technique. Furthermore, a micro-needle with a cross-shape assembly was prepared to grip the epidemical layer firmly throughout the wound curing procedure.

\subsection{Early Phase Drugs}

$3 \mathrm{D}$ printing is gaining traction in the manufacturing industry, with the benefits of improving productivity and lowering both the cost and number of human-based faults [94,95]. Given its enormous flexibility and capacity to modify and construct a range of simple to complicated geometries, 3D printing has altered production rates with process automation. 3D printing is swiftly transforming pharmaceutical production to achieve elevated quality therapeutic products with improved process sturdiness in bio-pharmaceutical product evolution, where there is a dependence on medicines manufacturing via conventional manufacturing procedures $[96,97]$. Furthermore, 3D printing has proved its efficiency in biomedical engineering for diagnostics and treatments. 
In this section, we present an updated outline of the above-mentioned 3D printing techniques, in terms of product development and their usage for medical applications [98-100]. Drug development initial step involves the APIs designing as a feasible preparation for medical well-being and effectiveness studies. To produce a medical dose that can be used to assess the new medicine effects, a thorough inspection of the API physico-chemical features is mandatory. With minor time, effort and resources investments, 3D printing can be applied to model drug doses in the medicine initial stage of development [101,102]. It allows the dosage quick printing with high dose flexibility and bio-availability properties that are essential for various groups in diverse topographical areas. It complies with the needs of many clinical sites to expedite the development of clinical investigations in a short time. Such benefits are not linked to the traditional production, which is costly owing to the larger lot size and labor requirements, and necessitates comprehensive pre-manufacturing studies to optimize the dosage formula $[103,104]$.

\subsection{Complex Drugs}

3D printing can be beneficial to design complex drugs, containing numerous amounts of therapeutic medicines. In traditional medicine doses, patients are required to consume several tablets of a single disorder to sustain drug quantities in the body [105]. Decreased patient acquiescence, missed dosage causing blood level oscillation, and high expenditures are all pros of this old technique. Instead, 3D printing allows for the manufacturing of personalized doses in the shape of poly-pills containing numerous drugs [106]. Patients are advised to take polypills, which can provide benefits from the 3D printing process to medical transport. The formation of self-sufficient medication practices is gaining traction at the community level. This concept is also known as "community medicine". It is especially important in the areas where healthcare personnel are insufficient to fulfill the community demand.

In this regard, 3D printing can aid in the benchmark establishment for community medicine success. Patients can determine their dosage demands based on their disease requirements rather than depending solely on the doctors $[97,101,107]$. The devoted software uses the provided information, which is utilized for medicine printing using an individual 3D printer. This process can easily be carried out at the community drugstore or household. Remote towns, military stations, and catastrophe administration zones can take advantage of this technique. The benefits of this strategy include reduction in medicines deficiencies and wastage, easier medicines access, and less dependency on paramedical staff. At the clinical drugstore, 3D printing can be utilized in the same way as "community medicine". Patients typically take their doctor prescriptions to the pharmacist, and receive their medication [108]. In today's world, the pharmacist may employ a 3D printer to give the medicine in a customized format utilizing the physician's information. It can eliminate any medicine shortages and make individualized medicine treatment more widely available in clinical practices [99].

\subsection{Unique Drugs}

The development of dense medical doses has been affected by 3D printing. When compared to traditional procedures, it gives dosage with high flexibility and efficacy [109]. Mixing, crushing, densification and condensation are the steps involved in the traditional manufacturing of solid doses, and they are all performed batch-by-batch. As a result, traditional multi-step manufacturing is related to substantial batch-wise changeability and inferior process sturdiness. For diverse solid doses in case of various human body sections, including implants, stents, transdermic, rectum and internal vaginal instruments, 3D printing permits simple product development with quick conceptualization, modelling and optimization $[105,110,111]$. Following the foremost medicinal 3D printed product endorsement in the case of "epilepsy" treatment, 3D printing gained interest for various other medical items. The medical sector is repeatedly facing supervisory provocations concerning quality for inadequate dependency on the sturdiness of the medical product 
manufactured via traditional manufacturing methods. To this issue, $3 \mathrm{D}$ printing is a new method with the potential to manufacture new products with high flexibility with customized doses according to the patient's requirements [101,112]. It also minimizes the processing stages, expenses and catastrophe risks, thus improving the product quality and customer happiness. Table 3 contains examples of using 3D printing in the development of various medications.

Table 3. Different medical doses manufactured by 3D printing process.

\begin{tabular}{|c|c|c|c|c|}
\hline Dosage & Design & Printing Method & Applications & References \\
\hline Panadol. & Instant release pill. & Selective laser sintering. & $\begin{array}{l}\text { The action takes } \\
\text { place quickly. }\end{array}$ & [48] \\
\hline $\begin{array}{l}\text { Pentoxifylline, } \\
\text { Theophylline. }\end{array}$ & Instant release pill. & $\begin{array}{l}\text { Fused depositing } \\
\text { modelling. }\end{array}$ & $\begin{array}{l}\text { The action takes } \\
\text { place quickly. }\end{array}$ & [113] \\
\hline $\begin{array}{l}\text { Mesalamine, Losartan, } \\
\text { Theobromine, } \\
\text { Prednisone. }\end{array}$ & Instant release pill. & $\begin{array}{l}\text { Fused depositing } \\
\text { modelling. }\end{array}$ & $\begin{array}{l}\text { The action takes } \\
\text { place quickly. }\end{array}$ & [114] \\
\hline Albuterol. & Administered release pill. & $\begin{array}{l}\text { Fused depositing } \\
\text { modelling. }\end{array}$ & $\begin{array}{l}\text { Start acting in the } \\
\text { intestinal tract. }\end{array}$ & [115] \\
\hline Panadol. & Pill for Enteric. & $\begin{array}{l}\text { Fused depositing } \\
\text { modelling. }\end{array}$ & $\begin{array}{c}\text { To focus on the particular } \\
\text { body regime. }\end{array}$ & [116] \\
\hline $\begin{array}{l}\text { Theobromine, } \\
\text { Albuterol, } \\
\text { Paracetamol. }\end{array}$ & Pill for shell core. & $\begin{array}{l}\text { Fused depositing } \\
\text { modelling. }\end{array}$ & Start acting in the intestines. & [117] \\
\hline Atorvastatin. & Floating pill. & Inkjet printing. & For oral active treatments. & [118] \\
\hline Phenytoin. & Administered release pill. & $\begin{array}{l}\text { Fused depositing } \\
\text { modelling. }\end{array}$ & $\begin{array}{c}\text { To focus on the particular } \\
\text { body regime. }\end{array}$ & [69] \\
\hline Mesalamine, Panadol. & Tablet with torus profile. & Stereolithography. & $\begin{array}{l}\text { Tablet releasing time can } \\
\text { be controlled. }\end{array}$ & [119] \\
\hline Metamizole. & Pill for oral use. & $\begin{array}{l}\text { Fused depositing } \\
\text { modelling. }\end{array}$ & $\begin{array}{l}\text { To focus on the particular } \\
\text { body regime. }\end{array}$ & [52] \\
\hline Ibuprofen. & Pill for oral use. & Inkjet printing. & $\begin{array}{l}\text { To focus on the particular } \\
\text { body regime. }\end{array}$ & [120] \\
\hline Panadol. & Round tablet. & Inkjet printing. & $\begin{array}{l}\text { To focus on the particular } \\
\text { body regime. }\end{array}$ & [121] \\
\hline Dexamethasone. & Pill with modified dose. & $\begin{array}{l}\text { Fused depositing } \\
\text { modelling. }\end{array}$ & $\begin{array}{l}\text { The release time can } \\
\text { be redefined. }\end{array}$ & [122] \\
\hline $\begin{array}{l}\text { Mesalamine, } \\
\text { Azathioprine. }\end{array}$ & Pill with modified dose. & $\begin{array}{l}\text { Fused depositing } \\
\text { modelling. }\end{array}$ & $\begin{array}{c}\text { The release time can } \\
\text { be redefined. }\end{array}$ & {$[72,123]$} \\
\hline
\end{tabular}

\subsection{Solid Oral Drugs}

Solid oral drugs mainly comprise tablets with various geometrical and functional characteristics. 3D printing can manufacture different dosages with numerous medications to attain instant or prolonged release. Such medicines include rectum-, oral- and aspirinbased pills. Further, 3D printing increases the dissolution medicines which are poorly soluble $[105,110,124,125]$. To ensure quality, medicine transport structure by 3D printing must be exposed to regular pharmacopeial testing, comprised of rigidity, crumbliness, fragmentation and diffusing period assessment. Instant release pills are needed for the diseases that need quick medication. Medications can be divided into (a) fast resolving, (b) dispersible, (c) oral pills [97]. Traditional manufacturing of these medicines involves various steps, including proper quantity selection of ingredients to acquire required performance and machining. Using 3D printing, these formulations can be manufactured effectively. Generally, the medicine is distributed in a binding liquid, which is utilized for printing. FDM has also been applied to manufacture pills using polymeric filaments stuffed with drugs. Polymers, including polyvidone, Hypromellose, 2-hydroxypropyl ether and Polycaprolactone have been applied to filaments' formulation, stuffed with drugs, and printed by extrusion (hot) process [126-128]. By changing the concentration of polymers within the filament, the medicine loading and releasing efficacies can be modified. Fur- 
thermore, 3D printing also delivers opportunities to change the pill/tablet's geometrical features in correspondence to the medicine filling densities. These features are attained by varying the CAD model.

Furthermore, film characteristics optimization can be reached by altering the binding material ratio, inclusion of plasticizers and operating conditions [96]. These parameters also control the medication release performance. In contrary to instant release medicines, improved release medicines yield a characteristic medication spread outline that can be modified according to the patient's disease. Different improved release medication systems have been manufactured, including complete-, prolonged-, administered-, and substitutedrelease $[37,99,108]$. Additional cases of improved release medication systems contain chronotherapeutic-, histopathological-, and multiple-APIs-release systems. Consequently, $3 \mathrm{D}$ printing is a valuable method to attain the intricate geometries of medicines. Rectumrelease medicines were manufactured to regulate the medicine release and ingredient expansion within the intestines after providing safety to the medicine against the gastric acidic (stomach). These medicines need pre-coating with acid-resistant polymers to avoid the deprivation of drugs within the stomach. The pre-coating needs very good control of operating conditions to evade variations that occurred during the release of the medicine. For this purpose, 3D printing can be utilized to model the whole release structures by defining the particular area for medication release [102]. Different filling agents and polymeric materials are combined into the pill's precise areas to attain personalized medication release outlines. Fused deposition modelling and binder jet printing can specifically be applied to design and print enteric-based releasing setups. Several enteric-based coating polymeric materials, including Hypromellose acetate succinate and 2-Methylpropenoic acid, were adopted for the prolonged spread of medication in the bowel section [129].

A medication in tablet or pill form, with various APIs, is very tough due to the larger dosage quantity and can cause unsuitability among medication ingredients, leading to swallowing problems, thus causing deprived patient agreement. To solve this specific problem, 3D printing can produce a pill/tablet with various medicines, which can be swallowed easily $[95,130]$. It decreases the doses in huge amounts. Multiple-API doses are beneficial in poly-pharmacy and for the group of patients consuming numerous medicines for different treatments. These tablets are also improving patient's acquiescence by eliminating medicine blunders. Moreover, the multi-layered dose with various medicines in each layer can deliver the anticipated therapy to cure the given disease. For instance, glyceryl guaiacolate medicine has two layers: (a) an instant release and (b) a prolonged release. This medicine has a mixture of hydroxypropyl methylcellulose and alcosperse that can be used to attain the anticipated modification spread outline [18]. Supervision-based release setups deliver medication spread up to a specific time. They have medicines distributed within a polymeric material (matrix). Such preparations via traditional techniques include wet and dry precipitation, densification and layering approaches. It also involves manufacturing control and systematic product optimization and operating conditions to attain the optimum release outline of a given medicine. Though, a high degree of variation and accompanying expenses result in an impact. Otherwise, 3D printing can be utilized to manufacture matrix-based medications, specifically for those consuming more than one medicine such as poly-pill [103].

Pulsatile-secretion-based releasing setups are the pills that have more than one APIs, exhibiting medicine release after a specified delay. They have essential drugs with the APIs placed within the tablet which is a time-dependent polymeric material and gives the anticipated medicine spreading. Pulsatile-secretion-based medicines can be used to cure ailments controlling the physical and physiological changes. Due to the intricate preparation steps involved by such types of pills, it is not feasible to manufacture them via traditional methods. In these medicines, a specific control on the releasing outline needs crucial control over polymeric material aggregation and modelling suitability. Fused deposition modelling and stereolithography can assist in preparing such medications. 
Recently, FDM is used to develop Pulsatile-secretion-based releasing pills to attain doublephase medication releasing outlines for Glucotrol in the case of diabetic patients [111].

Floating medicine transportation setups shaped by 3D printing are also efficient in refining the drug's bio-availability by elevating the gastro-retentive capability to a prolonged period. These setups are available in various kinds, including reverence pills filled with a permeable film to entrap air [104]. Fused deposition modelling or binder jet printing have been used in the case of gastro-retentive doses printing. Hypromellose, 1-polyacrylic acid, 2-Methylpropenoic acid have proved their 3D printing for gastro applications. Bio-mimetic medicine transportation setups are applied to enhance the bio-pharmaceutical medicines functioning for oral applications. These medicines face various difficulties related to alternations in modification absorptivity due to deprived emulsification, rectum penetrability and quick stomach draining [131]. To resolve these issues, medications are usually manufactured by solid dispersal with hydrophilic filling materials, including polyethylene glycol, ethanol, Hydroxypropyl methylcellulose acetate succinate, macrocyclic oligosaccharides, polyvinylpyrrolidone, hydroxypropyl methylcellulose, N-N-Dimethylacetamide and Soluplus-1. These filling materials behave as bio-availability boosters to resolve the difficulties mentioned above and increase the medicine Pharmacokinetics absorption coefficient. It is much easier to customize and print a mixture of various filling materials using fused deposition modelling. Scientists have recently initiated to adopt the 3D printing method in the development of lipid-based medicines transport setups commonly applied to enhance the bio-availability of oral-based medicines [125].

\subsection{Polymeric Drugs}

Poly (vinyl alcohol), designated as PVAL, is a biocompatible polymeric material that has decent solubility in water but poor ethanol solubility and is inexplicable in various organic diluents. PVAL is generally obtained by the hydrolysis of poly (vinyl acetate). PVAL has no odor and is a thermoplastic material [132,133]. It is also utilized to produce polymeric multiple-layered material for 3D printing via IP technique. The ink utilized for this purpose contained liquid PVAL solutions with propanetriol to prevent nozzle obstruction. Because of its viscidness, the ink's molecular weight had an impact on its printing. High and low molecular weights of PVAL were employed to generate a precise viscidness series in combination with 3D models. PVAL inks with elevated molecular weights can last up to six months duration without losing their shade. At declined shearing rates, all inks gave pseudoplastic and thixotropic behaviors, while at elevated shearing rates, all inks yielded Newtonian behavior [134].

Polycaprolactone (PCL) polymer is an important hydrophobic semi-crystalline polymer with low molecular weight and high crystallinity. PCL also behaves as bio-degradable framing material [135]. Beck et al. 3D printed the pills with PCL and eudragit stuffed with nano-polymers and printed via fused deposition modelling. The purpose of this study was to identify the filling effect on the medicines. The printer's scanning speed was set at $90 \mathrm{~mm} / \mathrm{s}$, while $50 \%$ and $100 \%$ fillings were carried out. It was found that the medicines with $50 \%$ filling yielded a faster releasing rate [136].

Gelatin methacrylamide (GM) is a naturally achieved cost-effective bio-material [137], photo-cross-linkable substantial that uses photo-patterning methods to separate a specific morphology or three-dimensional designs. Photo-patterning is a process that uses optical rays to prepare outlines for any provided material [138]. To make 3D microgels using GM, Fan et al. developed a dual-steps photo-patterning approach [139]. It was carried out to extract a single neuron from micro constructions. GM hydrogels were produced via a photo mask and relocated to a crystal slide covered with 3-propyl methacrylate (3-PM). Following on, the micro-patterned hydrogels were submerged into GM solution-loaded cells. Photo-polymerization was used in the second stage, allowing each cell to be trapped in the gap with reasonable efficiency. After growing within the altered GM hydrogels, it was discovered that a single neuron may expand, giving a useful tool for studying axonal growth. 
Nano-celluloses (NCs) are usually prepared via biochemical techniques [140]. NCs have distinct features such as elevated strength to deposition height ratio and surface interaction, thus yielding steady and viable products [141,142]. NCs are significantly an extremely interesting bio-degradable material that can simply be used to make hydrogels. The fibril entanglement suppleness and tendency are sufficiently high in these materials [143]. An elevated shearing viscosity with robust thinning characteristics makes them appropriate for 3D printing [144]. Nano-crystal (NCYs), a category of NCs, provide elevated toughness and outstanding viability that can strengthen the matrix with the least loading capability. NCYs have a very high crystallinity $[145,146]$. Wang et al. determined that Bis-acyl phosphine oxides (BAO) + NCYs can yield a specific monomer without utilizing any sort of extra chemical bonding. Furthermore, it was utilized in the 3D printing process to form $3 \mathrm{D}$ objects without any support $[147,148]$.

\section{3D Printing and Tissue Engineering}

The goal of customized medicine delivery is to offer an effective product with fewer adverse side effects and better appropriateness. The antiepileptic medication "levetiracetam" was the primary FDA-approved 3D-printed medication. The pharmacologic activity was parallel to the traditional pills, although the solubilization period was shorter. After implementing the "Zip-dose" method, "Aprecia Pharmaceuticals" promoted a medication named "Spritam". These pills were synthesized by selective laser melting. Its primary deposit contained APIs, filling materials, and a binder. The medication, having a dose amount of $1000 \mathrm{mg}$, was able to dissolve quickly within a few seconds [149]. Khaled et al. prepared a poly-pill with a self-sufficient and controlled releasing outline [76]. This technique was able to manufacture medicine for the human beings who are compelled to consume discrete pills in case of various diseases. Poly-pill was used for heat treatment using an instant releasing outline comprising two sections for acetylsalicylate and apo-hydro, and three separate sections for slektine, tenormin and altace. Anti-cancer medications encounter problems while arriving at the action site, and also get stuck in other organs, thus causing poisonousness. Similar to the vein injection and oral medicines, the traditional setups also flop, owing to the medication's lower solubility, causing an increase in cancer patient problems. Therefore, modern tools can resolve the traditional medication limitation. Recently, a blotch was manufactured by combining efudex, 2-oxepanone homopolymer and polyglactin-910, which was effectively fixed on the pancreatic cancer area [150-152].

During organ transplantation, 3D printing of body tissues and key organs is crucial for patients. Given the scarcity of organ donors, 3D printing completed organs can bring a big influence on transplant waiting lists [153]. Organ printing has the potential to use the $3 \mathrm{D}$ printing method to develop tissues and organs utilizing a layer-wise accumulation method. Biomaterials, including collagen, hydrogels and various other synthetic materials are usually adopted in bio-printing to produce 3D tissues. In addition, stem cells are cultivated on hydrogel (supporting base) and used as a bio-link in the printing process [154]. The quality of the printed organ is usually identified by a variety of functional features, including material toughness, permeability and structure. Various pros of 3D bio-printing over conventional manufacturing processes include inexpensive printing, excellent shape accuracy and organ size, higher productivity, and visualization [154]. Inkjet printing and extrusion-based printing processes are commonly used techniques. These methods rely on bio-ink deposition over a base plate, guided by a 3D model of organs or tissues generated by computer-aided design software. The recent manufacturing of a full human heart and valves is an example of 3D-printed organs [155]. Bio-ink, a mixture of hydrogel derived from fatty acids and human tissues, was employed to manufacture organs via inkjet printing [156]. The printing of a heart with blood veins took $3-4 \mathrm{~h}$, which was placed in a nutrient solution and oxygen was provided for a few days. As a result, the cells began to beat and behave like a functioning human heart [157]. Intriguingly, live 3D printing is also possible. According to the experts at the University of Sao Paulo Human Genome and Stem Cell Research Center, 3D printing of the liver organoids is achievable, 
and these organoids with mini-liver presented similar features to complete human liver cells [158]. Moreover, doctors at the University of Michigan, USA, used 3D printers and xray computed tomography scans to produce lungs airways [159]. Furthermore, 3D printing is also used to manufacture bladders [160]. At Boston Children Hospital, USA, researchers developed 3D printed bladders for patients with urine problems due to bladder disease. For dental surgeries, 3D printing is appropriate to manufacture teeth to substitute decayed teeth [161].

\section{Conclusions and Future Outlook}

As a result of new lifestyles, people are relying more on an improved form of medication rather than concentrating on a healthy diet. For particular cases, one usually takes various doses depending on the number of diseases. As a result, customized medicine can have a lot of potential in terms of medicine designing and preparation based on the needs of particular patients. The rapid expansion of 3D-printed formulations using diverse processes, including inkjet printing, fused deposition modelling, material extrusion and stereolithography, have gained the healthcare industry's attention. An inkjet printing technology can produce the more regulated formulation, while fused deposition modeling can reach dosage precision owing to the high resolution. Within the last few years, researchers have employed 3D printing to produce numerous doses with little material waste. Low-cost medication devices and poly-pills can be fabricated rapidly and safely. The extrusion-based bio-printing can be used to generate a variety of biological tissues with accurate structures that are safe for human usage. Patients with chronic diseases can receive therapy at an affordable price. The pharmaceutical company can also benefit since individualized 3D printing reduces market competition, resulting in more income. The potential for spatially tailored devices and formulations to treat diseases, ranging from infection to cancer, could open up new avenues for medical and pharmacological research. As a result, 3D printing can play a key role in the development of tailored medications and medical transport systems, resulting in significant advancements in medicine and healthcare.

Whilst technological improvements are constantly being made insofar as this notion is concerned, preliminary results appear promising. In particular, it is foreseen that $3 \mathrm{D}$ printing is well suited to be used within digital health domains, changing the face of pharmaceutical manufacture. A favorable aspect would include its adoption by the pharmaceutical industry as a feasible alternative to current fabrication methods. However, many would argue that this technology is still primitive and its goal is not to replace mass production but to complement it, for instance, in the production of complex dosage regimes of drugs with narrow therapeutic indices, where accurate dosing is needed to maintain treatment efficacy and patient safety, or biological products, which are often unstable under storage conditions. Alternatively, 3D printing could be leveraged for the production of on-demand dosage forms tailored to the needs of challenging patient subgroups, such as young children and the elderly, where dosing requirements can be markedly different when compared with adults.

By integrating a fourth dimension such as time, it is possible to achieve dynamic structures with programmable shapes, properties, or functionality. The use of novel strategies such as $4 \mathrm{D}$ printing is advantageous within the pharmaceutical sector, especially for the advancement of controlled drug delivery. By evaluating smart materials currently applied in pharmaceutical formulation, the initial applications and beneficial attributes of $4 \mathrm{D}$ printing can be unveiled. For instance, by applying $4 \mathrm{D}$ printing to produce structures of high resolution and complexity, not only would the process improvement in terms of time and cost efficiency but also the opportunity for bespoke treatments emerge. Within pharmaceutics, the most valuable purpose of this process is the fabrication of engineered drug delivery devices for targeted therapies. This could be achieved by utilizing $\mathrm{pH}$ as a stimulus, permitting the affixation of formulations to specific regions in the gastrointestinal tract. In turn, the use of such smart systems provides superior drug absorption within the site of action, improving the efficacy of treatment. 
The integration of 3D printing into clinical practice could pave the way for a digital health revolution, changing the way medicines are designed and prescribed for patients. However, the healthcare sector is known for being notoriously resilient to change, owing to the presence of regulatory guidelines and clinical standards, both of which pose technical and quality control challenges. Though such regulations promote patient safety, they are often a stumbling block in the route of modern technological advancements. Indeed, as the evidence-base for 3D printing continues to grow, it is becoming obvious that action is required to translate the theoretical benefits of $3 \mathrm{D}$ printing into real-world benefits for patients.

To date, a limited number of in-vivo studies have been carried out albeit with highly promising results. In 2017, the first in vivo acceptability study was performed, whereby 3D printed dosage forms were designed to have a variety of different shapes and sizes, which were evaluated for ease of swallowing and handling in human volunteers [162]. Novel diamond shape structures were designed to be structurally raised enabling ease of handling in patients with dexterity challenges. In terms of swallowing, patients were found to prefer the torus, cylinder, and oblong shapes, demonstrating how different 3D printing geometries could be used to improve medication acceptability. Following on from this work, Liang, et al. undertook a first-in-human study of a 3D printed wearable oraldrug delivery device in the form of a mouthguard, designed to have tunable drug release rates [163]. University College London (UCL) in partnership with FabRx, a company focusing on using 3D printing for personalized medicines and devices, has also recently performed a world-first clinical study, whereby a 3D printer was integrated into a hospital pharmacy for personalized treatment of children with a rare metabolic disease [164]. Such advancements demonstrate the revolutionary potential of 3D printing, however further studies are required to progress this technology away from an academic concept toward real-world benefits for patients.

Currently, commercial 3D printers do not abide by Good Manufacturing Practice (GMP) requirements. As such, regulating their use to produce solid oral dosage forms in a clinical setting, e.g., local pharmacy or hospital, remains an unmet need. In addition, all aspects of the printing process would require a thorough evaluation to confirm that the final dosage forms are uniform. The use of multiple production sites adds further technical and logistic challenges, wherein it is difficult to ensure that the end-products are of consistent quality, due to the multiple variables affecting the process including different settings, hardware, raw material suppliers and operator training [165]. Thus, this instigates the need for quality control (QC) measurements, such as the use of nondestructive characterization methods, including process analytical technologies (PAT), such as near-infrared (NIR) spectroscopy [166-168], Raman spectroscopy [169-171] or colorimetry [172,173], to monitor drug performance and ensure requirements imposed by regulatory bodies are being fulfilled.

Author Contributions: Conceptualization, methodology, formal analysis, investigation, data curation, writing —original draft preparation, writing—review and editing: M.A.M. The author has read and agreed to the published version of the manuscript.

Funding: M.A.M has received financial support from the European Union's Horizon 2020 (H2020) research and innovation program under the Marie Skłodowska-Curie, grant agreement No. 764935.

Institutional Review Board Statement: Not applicable.

Informed Consent Statement: Not applicable.

Data Availability Statement: Not applicable.

Acknowledgments: M.A.M. acknowledges with thanks the European Union's Horizon 2020 (H2020) research and innovation program under the Marie Skłodowska-Curie, grant agreement No. 764935.

Conflicts of Interest: The author declares no conflict of interest. 


\section{References}

1. Vogenberg, F.R.; Barash, C.I.; Pursel, M. Personalized medicine-Part 1: Evolution and development into theranostics. Pharm. Ther. 2010, 35, 560.

2. Mancinelli, L.; Cronin, M.; Sadée, W. Pharmacogenomics: The promise of personalized medicine. AAPS PharmSci 2000, 2, 1-13. [CrossRef]

3. Abrahams, E.; Ginsburg, G.S.; Silver, M. The personalized medicine coalition: Goals and strategies. Am. J. Pharm. 2005, 5, 345-355. [CrossRef] [PubMed]

4. Langreth, B.R.; Waldholz, M. New Era of Personalized Medicine Targeting Drugs for Each Unique Genetic Profile. Oncologist 1999, 4, 426-427. [CrossRef] [PubMed]

5. Cobleigh, M.A.; Vogel, C.L.; Tripathy, D.; Robert, N.J.; Scholl, S.; Fehrenbacher, L.; Wolter, J.M.; Paton, V.; Shak, S.; Lieberman, G.; et al. Multinational Study of the Efficacy and Safety of Humanized Anti-HER2 Monoclonal Antibody in Women Who Have HER2-Overexpressing Metastatic Breast Cancer That Has Progressed After Chemotherapy for Metastatic Disease. J. Clin. Oncol. 1999, 17, 2639. [CrossRef]

6. Abrahams, E.; Silver, M. The case for personalized medicine. J. Diabetes Sci. Technol. 2009, 3, 680-684. [CrossRef] [PubMed]

7. Rizvi, U.Z. Looking forward, looking back. SAA Archaeol. Rec. 2008, 8, 6-8.

8. Soni, N.; Jain, K.; Gupta, U.; Jain, N.K. Controlled delivery of Gemcitabine Hydrochloride using mannosylated poly(propyleneimine) dendrimers. J. Nanoparticle Res. 2015, 17, 1-17. [CrossRef]

9. Mahmood, M.A.; Popescu, A.C.; Hapenciuc, C.L.; Ristoscu, C.; Visan, A.I.; Oane, M.; Mihailescu, I.N. Estimation of clad geometry and corresponding residual stress distribution in laser melting deposition: Analytical modeling and experimental correlations. Int. J. Adv. Manuf. Technol. 2020, 111, 77-91. [CrossRef]

10. Mahmood, M.A.; Visan, A.I.; Ristoscu, C.; Mihailescu, I.N. Artificial Neural Network Algorithms for 3D Printing. Materials 2021, 14, 163. [CrossRef]

11. Mahmood, M.A.; Popescu, A.C.; Oane, M.; Ristoscu, C.; Chioibasu, D.; Mihai, S.; Mihailescu, I.N. Three-Jet Powder Flow and Laser-Powder Interaction in Laser Melting Deposition: Modelling Versus Experimental Correlations. Metals 2020, 10, 1113. [CrossRef]

12. Chioibasu, D.; Mihai, S.; Mahmood, M.A.; Lungu, M.; Porosnicu, I.; Sima, A.; Dobrea, C.; Tiseanu, I.; Popescu, A.C. Use of X-ray computed tomography for assessing defects in Ti grade 5 parts produced by laser melting deposition. Metals 2020, 10, 1408. [CrossRef]

13. Mahmood, M.A.; Popescu, A.C.; Mihailescu, I.N. Metal Matrix Composites Synthesized by Laser-Melting Deposition: A Review. Materials 2020, 13, 2593. [CrossRef] [PubMed]

14. Gross, B.C.; Erkal, J.L.; Lockwood, S.Y.; Chen, C.; Spence, D.M. Evaluation of 3D printing and its potential impact on biotechnology and the chemical sciences. Anal. Chem. 2014, 86, 3240-3253. [CrossRef] [PubMed]

15. Belhabib, S.; Guessasma, S. Compression performance of hollow structures: From topology optimisation to design 3D printing. Int. J. Mech. Sci. 2017, 133, 728-739. [CrossRef]

16. Wu, B.M.; Borland, S.W.; Giordano, R.A.; Cima, L.G.; Sachs, E.M.; Cima, M.J. Solid free-form fabrication of drug delivery devices. J. Control Release 1996, 40, 77-87. [CrossRef]

17. Bartlett, S. Printing organs on demand. Lancet Respir. Med. 2013, 1, 684. [CrossRef]

18. Khaled, S.A.; Burley, J.C.; Alexander, M.R.; Roberts, C.J. Desktop 3D printing of controlled release pharmaceutical bilayer tablets. Int. J. Pharm. 2014, 461, 105-111. [CrossRef]

19. Ursan, I.; Chiu, L.; Pierce, A. Three-dimensional drug printing: A structured review. J. Am. Pharm. Assoc. 2013, 53, 136-144. [CrossRef]

20. Banks, J. Adding value in additive manufacturing: Researchers in the United Kingdom and Europe look to 3D printing for customization. IEEE Pulse 2013, 4, 22-26. [CrossRef]

21. Lee Ventola, C. Medical applications for 3D printing: Current and projected uses. Pharm. Ther. 2014, 39, 704-711.

22. Tagami, T.; Nagata, N.; Hayashi, N.; Ogawa, E.; Fukushige, K.; Sakai, N.; Ozeki, T. Defined drug release from 3D-printed composite tablets consisting of drug-loaded polyvinylalcohol and a water-soluble or water-insoluble polymer filler. Int. J. Pharm. 2018, 543, 361-367. [CrossRef] [PubMed]

23. Kadry, H.; Al-Hilal, T.A.; Keshavarz, A.; Alam, F.; Xu, C.; Joy, A.; Ahsan, F. Multi-purposable filaments of HPMC for 3D printing of medications with tailored drug release and timed-absorption. Int. J. Pharm. 2018, 544, 285-296. [CrossRef] [PubMed]

24. Wallin, T.J.; Pikul, J.; Shepherd, R.F. 3D printing of soft systems. Nat. Rev. Mate. 2018, 3, 84-100. [CrossRef]

25. Korte, C.; Quidbach, J. Formulation development and process analysis of drug-loaded filaments manufactured via hot-melt extrusion for 3D-printing of medicines. Phar. Dev. Tech. 2018, 23, 1117-1127. [CrossRef] [PubMed]

26. Awad, A.; Trenfield, S.J.; Gaisford, S.; Basit, A.W. 3D printed medicines: A new branch of digital healthcare. Int. J. Pharm. 2018, 548, 586-596. [CrossRef]

27. Norman, J.; Madurawe, R.D.; Moore, C.M.V.; Khan, M.A.; Khairuzzaman, A. A new chapter in pharmaceutical manufacturing: 3D-printed drug products. Adv. Drug Deliv. Rev. 2017, 108, 39-50. [CrossRef]

28. Hornung, C.H. The art of manufacturing molecules. Science 2019, 359, 273-274. [CrossRef] [PubMed] 
29. Ku, M.S.; Dulin, W. A biopharmaceutical classification-based Right-First-Time formulation approach to reduce human pharmacokinetic variability and project cycle time from First-In-Human to clinical Proof-of-Concept. Pharm. Dev. Technol. 2012, 17, 285-302. [CrossRef] [PubMed]

30. Goyanes, A.; Robles Martinez, P.; Buanz, A.; Basit, A.W.; Gaisford, S. Effect of geometry on drug release from 3D printed tablets. Int. J. Pharm. 2015, 494, 657-663. [CrossRef]

31. Moulton, S.E.; Wallace, G.G. 3-dimensional (3D) fabricated polymer based drug delivery systems. J. Control Release 2014, 193, 27-34. [CrossRef] [PubMed]

32. Future Challenges for Digital Healthcare. Available online: https://www.medicalnewstoday.com/articles/317022 (accessed on 13 January 2021).

33. Chen, D.; Heyer, S.; Ibbotson, S.; Salonitis, K.; Steingrímsson, J.G.; Thiede, S. Direct digital manufacturing: Definition, evolution, and sustainability implications. J. Clean. Prod. 2015, 107, 615-625. [CrossRef]

34. Cycle Pharmaceuticals to Use 3D Printing to Develop “Orphan Drugs". Available online: https:/ / www.cambridgeindependent. co.uk/business / cycle-pharmaceuticals-to-use-3d-printing-to-develop-orphan-drugs-9053341/ (accessed on 13 January 2021).

35. Leonards, H.; Engelhardt, S.; Hoffmann, A.; Pongratz, L.; Schriever, S.; Bläsius, J.; Wehner, M.; Gillner, A. Advantages and drawbacks of Thiol-ene based resins for 3D-printing. In Laser 3D Manufacturing II, Proceedings of the SPIE LASE, San Francisco, CA, USA, 7-12 February 2015; Helvajian, H., Piqué, A., Wegener, M., Gu, B., Eds.; SPIE: Bellingham, WA, USA, 2015; Volume 9353, p. 93530F.

36. Schubert, C.; Van Langeveld, M.C.; Donoso, L.A. Innovations in 3D printing: A 3D overview from optics to organs. Br. J. Ophthalmol. 2014, 98, 159-161. [CrossRef]

37. Khatri, P.; Shah, M.K.; Vora, N. Formulation strategies for solid oral dosage form using 3D printing technology: A mini-review. J. Drug Deliv. Sci. Technol. 2018, 46, 148-155. [CrossRef]

38. Mertz, L. New World of 3-D Printing Offers "Completely New Ways of Thinking": Q\&A with Author, Engineer, and 3-D Printing Expert Hod Lipson. IEEE Pulse 2013, 4, 12-14. [CrossRef]

39. Atreya, C.; Glynn, S.; Busch, M.; Kleinman, S.; Snyder, E.; Rutter, S.; AuBuchon, J.; Flegel, W.; Reeve, D.; Devine, D.; et al. Proceedings of the Food and Drug Administration public workshop on pathogen reduction technologies for blood safety 2018 (Commentary, p. 3026). Transfusion 2019, 59, 3002. [CrossRef]

40. Goole, J.; Amighi, K. 3D printing in pharmaceutics: A new tool for designing customized drug delivery systems. Int. J. Pharm. 2016, 499, 376-394. [CrossRef]

41. Derby, B. Inkjet Printing of Functional and Structural Materials: Fluid Property Requirements, Feature Stability, and Resolution. Annu. Rev. Mater. Res. 2010, 40, 395-414. [CrossRef]

42. Anany, H.; Brovko, L.; El Dougdoug, N.K.; Sohar, J.; Fenn, H.; Alasiri, N.; Jabrane, T.; Mangin, P.; Monsur Ali, M.; Kannan, B.; et al. Print to detect: A rapid and ultrasensitive phage-based dipstick assay for foodborne pathogens. Anal. Bioanal. Chem. 2018, 410, 1217-1230. [CrossRef]

43. Alomari, M.; Mohamed, F.H.; Basit, A.W.; Gaisford, S. Personalised dosing: Printing a dose of one's own medicine. Int. J. Pharm. 2015, 494, 568-577. [CrossRef] [PubMed]

44. Tekin, E.; Smith, P.J.; Schubert, U.S. Inkjet printing as a deposition and patterning tool for polymers and inorganic particles. Soft Matter 2008, 4, 703-713. [CrossRef] [PubMed]

45. Maleki, H.; Bertola, V. Recent advances and prospects of inkjet printing in heterogeneous catalysis. Catal. Sci. Technol. 2020, 10, 3140-3159. [CrossRef]

46. Dimitrov, D.; Schreve, K.; De Beer, N. Advances in three dimensional printing-State of the art and future perspectives. Rapid Prototyp. J. 2006, 12, 136-147. [CrossRef]

47. Konta, A.; García-Piña, M.; Serrano, D. Personalised 3D Printed Medicines: Which Techniques and Polymers Are More Successful? Bioengineering 2017, 4, 79. [CrossRef]

48. Fina, F.; Goyanes, A.; Gaisford, S.; Basit, A.W. Selective laser sintering (SLS) 3D printing of medicines. Int. J. Pharm. 2017, 529, 285-293. [CrossRef]

49. Hoy, M.B. 3D Printing: Making Things at the Library. Med. Ref. Serv. Q. 2013, 32, 93-99. [CrossRef]

50. Prasad, L.K.; Smyth, H. 3D Printing technologies for drug delivery: A review. Drug Dev. Ind. Pharm. 2016, 42, 1019-1031. [CrossRef]

51. Ratheesh, G.; Venugopal, J.R.; Chinappan, A.; Ezhilarasu, H.; Sadiq, A.; Ramakrishna, S. 3D Fabrication of Polymeric Scaffolds for Regenerative Therapy. ACS Biomater. Sci. Eng. 2017, 3, 1175-1194. [CrossRef]

52. Wang, J.; Goyanes, A.; Gaisford, S.; Basit, A.W. Stereolithographic (SLA) 3D printing of oral modified-release dosage forms. Int. J. Pharm. 2016, 503, 207-212. [CrossRef]

53. Melchels, F.P.W.; Feijen, J.; Grijpma, D.W. A review on stereolithography and its applications in biomedical engineering. Biomaterials 2010, 31, 6121-6130. [CrossRef]

54. Schmidleithner, C.; Kalaskar, D.M. Stereolithography. In 3D Printing; IntechOpen: London, UK, 2018.

55. Wong, K.V.; Hernandez, A. A Review of Additive Manufacturing. ISRN Mech. Eng. 2012, 2012, 1-10. [CrossRef]

56. Zhang, J.; Hu, Q.; Wang, S.; Tao, J.; Gou, M. Digital light processing based three-dimensional printing for medical applications. Int. J. Bioprinting 2020, 6, 12-27. [CrossRef] [PubMed] 
57. Stansbury, J.W.; Idacavage, M.J. 3D printing with polymers: Challenges among expanding options and opportunities. Dent. Mater. 2016, 32, 54-64. [CrossRef]

58. Panwar, A.; Tan, L. Current Status of Bioinks for Micro-Extrusion-Based 3D Bioprinting. Molecules 2016, 21, 685. [CrossRef]

59. You, F.; Eames, B.F.; Chen, X. Application of Extrusion-Based Hydrogel Bioprinting for Cartilage Tissue Engineering. Int. J. Mol. Sci. 2017, 18, 1597. [CrossRef]

60. Duarte Campos, D.F.; Blaeser, A.; Weber, M.; Jäkel, J.; Neuss, S.; Jahnen-Dechent, W.; Fischer, H. Three-dimensional printing of stem cell-laden hydrogels submerged in a hydrophobic high-density fluid. Biofabrication 2013, 5, 15003-15014. [CrossRef] [PubMed]

61. Maher, P.S.; Keatch, R.P.; Donnelly, K.; MacKay, R.E.; Paxton, J.Z. Construction of 3D biological matrices using rapid prototyping technology. Rapid Prototyp. J. 2009, 15, 204-210. [CrossRef]

62. Marga, F.; Jakab, K.; Khatiwala, C.; Shepherd, B.; Dorfman, S.; Hubbard, B.; Colbert, S.; Gabor, F. Toward engineering functional organ modules by additive manufacturing. Biofabrication 2012, 4, 022001. [CrossRef] [PubMed]

63. Phillippi, J.A.; Miller, E.; Weiss, L.; Huard, J.; Waggoner, A.; Campbell, P. Microenvironments Engineered by Inkjet Bioprinting Spatially Direct Adult Stem Cells Toward Muscle- and Bone-Like Subpopulations. Stem Cells 2008, 26, 127-134. [CrossRef]

64. Duan, B.; Hockaday, L.A.; Kang, K.H.; Butcher, J.T. 3D Bioprinting of heterogeneous aortic valve conduits with alginate/gelatin hydrogels. J. Biomed. Mater. Res.-Part A 2013, 101, 1255-1264. [CrossRef] [PubMed]

65. Markstedt, K.; Mantas, A.; Tournier, I.; Martínez Ávila, H.; Hägg, D.; Gatenholm, P. 3D bioprinting human chondrocytes with nanocellulose-alginate bioink for cartilage tissue engineering applications. Biomacromolecules 2015, 16, 1489-1496. [CrossRef]

66. Fedorovich, N.E.; Alblas, J.; De Wijn, J.R.; Hennink, W.E.; Verbout, A.B.J.; Dhert, W.J.A. Hydrogels as extracellular matrices for skeletal tissue engineering: State-of-the-art and novel application in organ printing. Tissue Eng. 2007, 13, 1905-1925. [CrossRef] [PubMed]

67. Hsieh, F.-Y.; Lin, H.-H.; Hsu, S.-H. 3D bioprinting of neural stem cell-laden thermoresponsive biodegradable polyurethane hydrogel and potential in central nervous system repair. Biomaterials 2015, 71, 48-57. [CrossRef] [PubMed]

68. Suntornnond, R.; An, J.; Chua, C.K. Roles of support materials in 3d bioprinting-Present and future. Int. J. Bioprinting 2017, 3, 83-86. [CrossRef] [PubMed]

69. Kyobula, M.; Adedeji, A.; Alexander, M.R.; Saleh, E.; Wildman, R.; Ashcroft, I.; Gellert, P.R.; Roberts, C.J. 3D inkjet printing of tablets exploiting bespoke complex geometries for controlled and tuneable drug release. J. Control Release 2017, 261, 207-215. [CrossRef]

70. Daly, R.; Harrington, T.S.; Martin, G.D.; Hutchings, I.M. Inkjet printing for pharmaceutics-A review of research and manufacturing. Int. J. Pharm. 2015, 494, 554-567. [CrossRef] [PubMed]

71. Sandler, N.; Salmela, I.; Fallarero, A.; Rosling, A.; Khajeheian, M.; Kolakovic, R.; Genina, N.; Nyman, J.; Vuorela, P. Towards fabrication of 3D printed medical devices to prevent biofilm formation. Int. J. Pharm. 2014, 459, 62-64. [CrossRef]

72. Goyanes, A.; Buanz, A.B.M.; Hatton, G.B.; Gaisford, S.; Basit, A.W. 3D printing of modified-release aminosalicylate (4-ASA and 5-ASA) tablets. Eur. J. Pharm. Biopharm. 2015, 89, 157-162. [CrossRef]

73. Kollamaram, G.; Croker, D.M.; Walker, G.M.; Goyanes, A.; Basit, A.W.; Gaisford, S. Low temperature fused deposition modeling (FDM) 3D printing of thermolabile drugs. Int. J. Pharm. 2018, 545, 144-152. [CrossRef]

74. Chockalingam, K.; Jawahar, N.; Chandrasekhar, U. Influence of layer thickness on mechanical properties in stereolithography. Rapid Prototyp. J. 2006, 12, 106-113. [CrossRef]

75. Martinez, P.R.; Goyanes, A.; Basit, A.W.; Gaisford, S. Fabrication of drug-loaded hydrogels with stereolithographic 3D printing. Int. J. Pharm. 2017, 532, 313-317. [CrossRef] [PubMed]

76. Khaled, S.A.; Burley, J.C.; Alexander, M.R.; Yang, J.; Roberts, C.J. 3D printing of five-in-one dose combination polypill with defined immediate and sustained release profiles. J. Control Release 2015, 217, 308-314. [CrossRef] [PubMed]

77. Khaled, S.A.; Burley, J.C.; Alexander, M.R.; Yang, J.; Roberts, C.J. 3D printing of tablets containing multiple drugs with defined release profiles. Int. J. Pharm. 2015, 494, 643-650. [CrossRef]

78. Gazzaniga, A.; Cerea, M.; Cozzi, A.; Foppoli, A.; Maroni, A.; Zema, L. A novel injection-molded capsular device for oral pulsatile delivery based on swellable/erodible polymers. AAPS PharmSciTech 2011, 12, 295-303. [CrossRef] [PubMed]

79. Melocchi, A.; Parietti, F.; Loreti, G.; Maroni, A.; Gazzaniga, A.; Zema, L. 3D printing by fused deposition modeling (FDM) of a swellable/erodible capsular device for oral pulsatile release of drugs. J. Drug Deliv. Sci. Technol. 2015, 30, 360-367. [CrossRef]

80. Samykano, M.; Selvamani, S.K.; Kadirgama, K.; Ngui, W.K.; Kanagaraj, G.; Sudhakar, K. Mechanical property of FDM printed ABS: Influence of printing parameters. Int. J. Adv. Manu. Techh. 2019, 102, 2779-2796. [CrossRef]

81. Yu, D.-G.; Branford-White, C.; Yang, Y.-C.; Zhu, L.-M.; Welbeck, E.W.; Yang, X.-L. A novel fast disintegrating tablet fabricated by three-dimensional printing. Drug Dev. Ind. Pharm. 2009, 35, 1530-1536. [CrossRef]

82. Sadarani, B.; Majumdar, A.; Kamble, P.; Paradkar, S.; Mathur, A.; Sachdev, S.; Chaudhari, P.; Mohanty, B. AB0079 Transdermal delivery of methotrexate in rheumatoid arthritis: Are we deep enough? BMJ 2017, 76, 1074.

83. Graybiel, A.; Knepton, J.; Shaw, J. Prevention of experimental motion sickness by scopolamine absorbed through the skin. Aviat. Sp. Environ. Med. 1976, 47, 1096-1100.

84. Mansfield, A.S.; Jatoi, A. Asphyxiation with a Fentanyl Patch. Case Rep. Oncol. 2013, 6, 242-244. [CrossRef]

85. Margetts, L.; Sawyer, R. Transdermal drug delivery: Principles and opioid therapy. Contin. Educ. Anaesth. Crit. Care Pain 2007, 7, 171-176. [CrossRef] 
86. Jessen, L.; Kovalick, L.J.; Azzaro, A.J. The selegiline transdermal system (emsam): A therapeutic option for the treatment of major depressive disorder. Pharm. Ther. 2008, 33, 212-246.

87. Abrams, L.S.; Skee, D.M.; Natarajan, J.; Wong, F.A.; Anderson, G.D. Pharmacokinetics of a contraceptive patch (Evra ${ }^{\text {TM } / O r t h o ~}$ Evra $^{\mathrm{TM}}$ ) containing norelgestromin and ethinyloestradiol at four application sites. Br. J. Clin. Pharmacol. 2002, 53, 141-146. [CrossRef]

88. Dhillon, S. Spotlight on rivastigmine transdermal patch: In dementia of the alzheimer's type. Drugs Aging 2011, 28, 927-930. [CrossRef] [PubMed]

89. Kirby, A.J. Method of Producing a Microneedle or Microimplant. U.S. Patent 8,192,787, 2012.

90. Boehm, R.D.; Miller, P.R.; Schell, W.A.; Perfect, J.R.; Narayan, R.J. Inkjet printing of amphotericin B onto biodegradable microneedles using piezoelectric inkjet printing. JOM 2013, 65, 525-533. [CrossRef]

91. Boehm, R.D.; Miller, P.R.; Singh, R.; Shah, A.; Stafslien, S.; Daniels, J.; Narayan, R.J. Indirect rapid prototyping of antibacterial acid anhydride copolymer microneedles. Biofabrication 2012, 4, 011002. [CrossRef]

92. Boehm, R.D.; Miller, P.R.; Hayes, S.L.; Monteiro-Riviere, N.A.; Narayan, R.J. Modification of microneedles using inkjet printing. AIP Adv. 2011, 1, 022139. [CrossRef]

93. Gittard, S.D.; Miller, P.R.; Jin, C.; Martin, T.N.; Boehm, R.D.; Chisholm, B.J.; Stafslien, S.J.; Daniels, J.W.; Cilz, N.; Monteiro-Riviere, N.A.; et al. Deposition of antimicrobial coatings on microstereolithography-fabricated microneedles. JOM 2011, 63, 59-68. [CrossRef]

94. Choonara, Y.E.; Du Toit, L.C.; Kumar, P.; Kondiah, P.P.D.; Pillay, V. 3D-printing and the effect on medical costs: A new era? Expert Rev. Pharm. Outcomes Res. 2016, 16, 23-32. [CrossRef]

95. Palo, M.; Holländer, J.; Suominen, J.; Yliruusi, J.; Sandler, N. 3D printed drug delivery devices: Perspectives and technical challenges. Expert Rev. Med. Devices 2017, 14, 685-696. [CrossRef]

96. Mertz, L. Dream it, design it, print it in 3-D: What can 3-D printing do for you? IEEE Pulse 2013, 4, 15-21. [CrossRef]

97. El Aita, I.; Ponsar, H.; Quodbach, J. A Critical Review on 3D-printed Dosage Forms. Curr. Pharm. Des. 2018, $24,4957-4978$. [CrossRef]

98. Alhnan, M.A.; Okwuosa, T.C.; Sadia, M.; Wan, K.W.; Ahmed, W.; Arafat, B. Emergence of 3D Printed Dosage Forms: Opportunities and Challenges. Pharm. Res. 2016, 33, 1817-1832. [CrossRef]

99. Araújo, M.; Sa-Barreto, L.; Gratieri, T.; Gelfuso, G.; Cunha-Filho, M. The Digital Pharmacies Era: How 3D Printing Technology Using Fused Deposition Modeling Can Become a Reality. Pharmaceutics 2019, 11, 128. [CrossRef] [PubMed]

100. Pravin, S.; Sudhir, A. Integration of 3D printing with dosage forms: A new perspective for modern healthcare. Biomed. Pharmacother. 2018, 107, 146-154. [CrossRef] [PubMed]

101. Norman, C.; Mello, M.; Choi, B. Identifying frequent users of an Urban emergency medical service using descriptive statistics and regression analyses. West. J. Emerg. Med. 2016, 17, 39-45. [CrossRef] [PubMed]

102. Guvendiren, M.; Molde, J.; Soares, R.M.D.; Kohn, J. Designing Biomaterials for 3D Printing. ACS Biomater. Sci. Eng. 2016, 2, 1679-1693. [CrossRef]

103. Gioumouxouzis, C.I.; Karavasili, C.; Fatouros, D.G. Recent advances in pharmaceutical dosage forms and devices using additive manufacturing technologies. Drug Discov. Today 2019, 24, 636-643. [CrossRef]

104. Awad, A.; Trenfield, S.J.; Goyanes, A.; Gaisford, S.; Basit, A.W. Reshaping drug development using 3D printing. Drug Discov. Today 2018, 23, 1547-1555. [CrossRef] [PubMed]

105. Lim, S.H.; Kathuria, H.; Tan, J.J.Y.; Kang, L. 3D printed drug delivery and testing systems-A passing fad or the future? Adv. Drug Deliv. Rev. 2018, 132, 139-168. [CrossRef] [PubMed]

106. Robles-Martinez, P.; Xu, X.; Trenfield, S.J.; Awad, A.; Goyanes, A.; Telford, R.; Basit, A.W.; Gaisford, S. 3D Printing of a Multi-Layered Polypill Containing Six Drugs Using a Novel Stereolithographic Method. Pharmaceutics 2019, 11, 274. [CrossRef]

107. Gu, B.K.; Choi, D.J.; Park, S.J.; Kim, M.S.; Kang, C.M.; Kim, C.H. 3-dimensional bioprinting for tissue engineering applications. Biomater. Res. 2016, 20, 1-8. [CrossRef] [PubMed]

108. Souto, E.B.; Campos, J.C.; Filho, S.C.; Teixeira, M.C.; Martins-Gomes, C.; Zielinska, A.; Carbone, C.; Silva, A.M. 3D printing in the design of pharmaceutical dosage forms. Pharm. Dev. Technol. 2019, 24, 1044-1053. [CrossRef] [PubMed]

109. Alruwaili, N.K.; Rizwanullah, M.; Abbas Bukhari, S.N.; Amir, M.; Ahmed, M.M.; Fazil, M. 3D Printing Technology in Design of Pharmaceutical Products. Curr. Pharm. Des. 2019, 24, 5009-5018. [CrossRef]

110. Chia, H.-N.; Wu, B.-M. Recent advances in 3D printing of biomaterials. J. Biol. Eng. 2015, 9, 1-14. [CrossRef]

111. Kolakovic, R.; Viitala, T.; Ihalainen, P.; Genina, N.; Peltonen, J.; Sandler, N. Printing technologies in fabrication of drug delivery systems. Expert Opin. Drug Deliv. 2013, 10, 1711-1723. [CrossRef] [PubMed]

112. Zhang, J.; Vo, A.Q.; Feng, X.; Bandari, S.; Repka, M.A. Pharmaceutical Additive Manufacturing: A Novel Tool for Complex and Personalized Drug Delivery Systems. AAPS PharmSciTech 2018, 19, 3388-3402. [CrossRef] [PubMed]

113. Okwuosa, T.C.; Stefaniak, D.; Arafat, B.; Isreb, A.; Wan, K.W.; Alhnan, M.A. A Lower Temperature FDM 3D Printing for the Manufacture of Patient-Specific Immediate Release Tablets. Pharm. Res. 2016, 33, 2704-2712. [CrossRef]

114. Sadia, M.; Sośnicka, A.; Arafat, B.; Isreb, A.; Ahmed, W.; Kelarakis, A.; Alhnan, M.A. Adaptation of pharmaceutical excipients to FDM 3D printing for the fabrication of patient-tailored immediate release tablets. Int. J. Pharm. 2016, 513, 659-668. [CrossRef]

115. Goyanes, A.; Chang, H.; Sedough, D.; Hatton, G.B.; Wang, J.; Buanz, A.; Gaisford, S.; Basit, A.W. Fabrication of controlled-release budesonide tablets via desktop (FDM) 3D printing. Int. J. Pharm. 2015, 496, 414-420. [CrossRef] 
116. Goyanes, A.; Fina, F.; Martorana, A.; Sedough, D.; Gaisford, S.; Basit, A.W. Development of modified release 3D printed tablets (printlets) with pharmaceutical excipients using additive manufacturing. Int. J. Pharm. 2017, 527, 21-30. [CrossRef]

117. Okwuosa, T.C.; Pereira, B.C.; Arafat, B.; Cieszynska, M.; Isreb, A.; Alhnan, M.A. Fabricating a Shell-Core Delayed Release Tablet Using Dual FDM 3D Printing for Patient-Centred Therapy. Pharm. Res. 2017, 34, 427-437. [CrossRef]

118. Chai, X.; Chai, H.; Wang, X.; Yang, J.; Li, J.; Zhao, Y.; Cai, W.; Tao, T.; Xiang, X. Fused deposition modeling (FDM) 3D printed tablets for intragastric floating delivery of domperidone. Sci. Rep. 2017, 7, 1-9. [CrossRef]

119. Lim, S.H.; Chia, S.M.Y.; Kang, L.; Yap, K.Y.L. Three-Dimensional Printing of Carbamazepine Sustained-Release Scaffold. J. Pharm. Sci. 2016, 105, 2155-2163. [CrossRef]

120. Zhang, L.; Krishnan, P.; Ehresman, D.J.; Smith, P.B.; Dutta, M.; Bagley, B.D.; Chang, S.-C.; Butenhoff, J.L.; Patterson, A.D.; Peters, J.M. Editor's Highlight: Perfluorooctane Sulfonate-Choline Ion Pair Formation: A Potential Mechanism Modulating Hepatic Steatosis and Oxidative Stress in Mice. Toxicol. Sci. 2016, 153, 186-197. [CrossRef]

121. Hsu, H.-Y.; Harris, M.T.; Toth, S.; Simpson, G.J. Drop printing of pharmaceuticals: Effect of molecular weight on PEG coatednaproxen/PEG 3350 solid dispersions. AIChE J. 2015, 61, 4502-4508. [CrossRef]

122. Yu, D.-G.; Branford-White, C.; Ma, Z.-H.; Zhu, L.-M.; Li, X.-Y.; Yang, X.-L. Novel drug delivery devices for providing linear release profiles fabricated by 3DP. Int. J. Pharm. 2009, 370, 160-166. [CrossRef] [PubMed]

123. Skowyra, J.; Pietrzak, K.; Alhnan, M.A. Fabrication of extended-release patient-tailored prednisolone tablets via fused deposition modelling (FDM) 3D printing. Eur. J. Pharm. Sci. 2015, 68, 11-17. [CrossRef] [PubMed]

124. Sandler, N.; Preis, M. Printed Drug-Delivery Systems for Improved Patient Treatment. Trends Pharmacol. Sci. 2016, 37, 1070-1080. [CrossRef] [PubMed]

125. Vithani, K.; Goyanes, A.; Jannin, V.; Basit, A.W.; Gaisford, S.; Boyd, B.J. An Overview of 3D Printing Technologies for Soft Materials and Potential Opportunities for Lipid-based Drug Delivery Systems. Pharm. Res. 2019, 36, 1-20. [CrossRef] [PubMed]

126. Haleem, A.; Javaid, M.; Khan, R.H.; Suman, R. 3D printing applications in bone tissue engineering. J. Clin. Orthop. Trauma 2020, 11, S118-S124. [CrossRef]

127. Huang, W.; Zhang, X. 3D printing: Print the future of ophthalmology. Investig. Ophthalmol. Vis. Sci. 2014, 55, 5380-5381. [CrossRef]

128. Jammalamadaka, U.; Tappa, K. Recent advances in biomaterials for 3D printing and tissue engineering. J. Funct. Biomater. 2018, 9 , 22. [CrossRef]

129. Jamróz, W.; Kurek, M.; Łyszczarz, E.; Brniak, W.; Jachowicz, R. Printing techniques: Recent developments in pharmaceutical technology. Acta Pol. Pharm.-Drug Res. 2017, 74, 753-763.

130. Osouli-Bostanabad, K.; Adibkia, K. Made-on-demand, complex and personalized 3D-printed drug products. Bioimpacts 2018, 8 , 77-79. [CrossRef] [PubMed]

131. Gopinathan, J.; Noh, I. Recent trends in bioinks for 3D printing. Biomater. Res. 2018, 22, 1-15. [CrossRef] [PubMed]

132. Marin, E.; Rojas, J.; Ciro, Y. A review of polyvinyl alcohol derivatives: Promising materials for pharmaceutical and biomedical applications. Afr. J. Pharm. Pharmacol. 2014, 8, 674-684. [CrossRef]

133. Baker, M.I.; Walsh, S.P.; Schwartz, Z.; Boyan, B.D. A review of polyvinyl alcohol and its uses in cartilage and orthopedic applications. J. Biomed. Mater. Res.-Part B Appl. Biomater. 2012, 100, 1451-1457. [CrossRef]

134. Salaoru, I.; Zhou, Z.; Morris, P.; Gibbons, G.J. Inkjet printing of polyvinyl alcohol multilayers for additive manufacturing applications. J. Appl. Polym. Sci. 2016, 133. [CrossRef]

135. Elomaa, L.; Teixeira, S.; Hakala, R.; Korhonen, H.; Grijpma, D.W.; Seppälä, J.V. Preparation of poly( $\varepsilon$-caprolactone)-based tissue engineering scaffolds by stereolithography. Acta Biomater. 2011, 7, 3850-3856. [CrossRef]

136. Beck, R.C.R.; Chaves, P.S.; Goyanes, A.; Vukosavljevic, B.; Buanz, A.; Windbergs, M.; Basit, A.W.; Gaisford, S. 3D printed tablets loaded with polymeric nanocapsules: An innovative approach to produce customized drug delivery systems. Int. J. Pharm. 2017, 528, 268-279. [CrossRef] [PubMed]

137. Lepowsky, E.; Tasoglu, S. 3D Printing for Drug Manufacturing: A Perspective on the Future of Pharmaceuticals. Int. J. Bioprinting 2017, 4, 119. [CrossRef]

138. Yue, K.; Trujillo-de Santiago, G.; Alvarez, M.M.; Tamayol, A.; Annabi, N.; Khademhosseini, A. Synthesis, properties, and biomedical applications of gelatin methacryloyl (GelMA) hydrogels. Biomaterials 2015, 73, 254-271. [CrossRef] [PubMed]

139. Fan, Y.; Xu, F.; Huang, G.; Lu, T.-J.; Xing, W. Single neuron capture and axonal development in three-dimensional microscale hydrogels. Lab Chip 2012, 12, 4724-4731. [CrossRef]

140. Klemm, D.; Heublein, B.; Fink, H.P.; Bohn, A. Cellulose: Fascinating biopolymer and sustainable raw material. Angew. Chem.-Int. Ed. 2005, 44, 3358-3393. [CrossRef] [PubMed]

141. Moon, R.J.; Martini, A.; Nairn, J.; Simonsen, J.; Youngblood, J. Cellulose nanomaterials review: Structure, properties and nanocomposites. Chem. Soc. Rev. 2011, 40, 3941-3994. [CrossRef]

142. De France, K.J.; Hoare, T.; Cranston, E.D. Review of Hydrogels and Aerogels Containing Nanocellulose. Chem. Mater. 2017, 29, 4609-4631. [CrossRef]

143. Ruiz-Palomero, C.; Soriano, M.L.; Valcárcel, M. Nanocellulose as analyte and analytical tool: Opportunities and challenges. TrAC-Trends Anal. Chem. 2017, 87, 1-18. [CrossRef] 
144. Håkansson, K.M.O.; Henriksson, I.C.; de la Peña Vázquez, C.; Kuzmenko, V.; Markstedt, K.; Enoksson, P.; Gatenholm, P. Solidification of 3D Printed Nanofibril Hydrogels into Functional 3D Cellulose Structures. Adv. Mater. Technol. 2016, 1, 1600096. [CrossRef]

145. Azouz, K.B.; Ramires, E.C.; Van Den Fonteyne, W.; El Kissi, N.; Dufresne, A. Simple method for the melt extrusion of a cellulose nanocrystal reinforced hydrophobic polymer. ACS Macro Lett. 2012, 1, 236-240. [CrossRef]

146. Cha, R.; Wang, C.; Cheng, S.; He, Z.; Jiang, X. Using carboxylated nanocrystalline cellulose as an additive in cellulosic paper and poly (vinyl alcohol) fiber paper. Carbohydr. Polym. 2014, 110, 298-301. [CrossRef] [PubMed]

147. Dai, L.; Cheng, T.; Duan, C.; Zhao, W.; Zhang, W.; Zou, X.; Aspler, J.; Ni, Y. 3D printing using plant-derived cellulose and its derivatives: A review. Carbohydr. Polym. 2019, 203, 71-86. [CrossRef]

148. Wang, J.; Chiappone, A.; Roppolo, I.; Shao, F.; Fantino, E.; Lorusso, M.; Rentsch, D.; Dietliker, K.; Pirri, C.F.; Grützmacher, H. All-in-One Cellulose Nanocrystals for 3D Printing of Nanocomposite Hydrogels. Angew. Chem. Int. Ed. 2018, 57, 2353-2356. [CrossRef] [PubMed]

149. SPRITAM (levetiracetam) Tablets. Available online: https://www.accessdata.fda.gov/drugsatfda_docs/nda/2015/207958Orig1 s000TOC.cfm (accessed on 17 January 2021).

150. Singh, J.; Jain, K.; Mehra, N.K.; Jain, N.K. Dendrimers in anticancer drug delivery: Mechanism of interaction of drug and dendrimers. Artif. Cells Nanomed. Biotechnol. 2016, 44, 1626-1634. [CrossRef] [PubMed]

151. Yi, H.-G.; Choi, Y.-J.; Kang, K.-S.; Hong, J.-M.; Pati, R.G.; Park, M.N.; Shim, I.K.; Lee, C.M.; Kim, S.C.; Cho, D.W. A 3D-printed local drug delivery patch for pancreatic cancer growth suppression. J. Control Release 2016, 238, 231-241. [CrossRef]

152. Jain, A.; Jain, K.; Mehra, N.K.; Jain, N.K. Lipoproteins tethered dendrimeric nanoconstructs for effective targeting to cancer cells. J. Nanoparticle Res. 2013, 15, 1-18. [CrossRef]

153. Tappa, K.; Jammalamadaka, U. Novel Biomaterials Used in Medical 3D Printing Techniques. J. Funct. Biomater. 2018,9 , 17. [CrossRef] [PubMed]

154. Parak, A.; Pradeep, P.; du Toit, L.C.; Kumar, P.; Choonara, Y.E.; Pillay, V. Functionalizing bioinks for 3D bioprinting applications. Drug Discov. Today 2019, 24, 198-205. [CrossRef]

155. Mosadegh, B.; Xiong, G.; Dunham, S.; Min, J.K. Current progress in 3D printing for cardiovascular tissue engineering. Biomed. Mater. 2015, 10, 034002. [CrossRef] [PubMed]

156. Lueders, C.; Jastram, B.; Hetzer, R.; Schwandt, H. Rapid manufacturing techniques for the tissue engineering of human heart valves. Eur. J. Cardio-Thorac. Surg. 2014, 46, 593-601. [CrossRef]

157. Noor, N.; Shapira, A.; Edri, R.; Gal, I.; Wertheim, L.; Dvir, T. 3D Printing of Personalized Thick and Perfusable Cardiac Patches and Hearts. Adv. Sci. 2019, 6. [CrossRef] [PubMed]

158. Goulart, E.; De Caires-Junior, L.C.; Telles-Silva, K.A.; Araujo, B.H.S.; Rocco, S.A.; Sforca, M.; De Sousa, I.L.; Kobayashi, G.S.; Musso, C.M.; Assoni, A.F.; et al. 3D bioprinting of liver spheroids derived from human induced pluripotent stem cells sustain liver function and viability in vitro. Biofabrication 2020, 12, 015010. [CrossRef] [PubMed]

159. 3D-Airway Printed Splint I Otolaryngology I Michigan Medicine I University of Michigan. Available online: https: / / medicine. umich.edu/dept/otolaryngology/3d-airway-printed-splint (accessed on 17 January 2021).

160. Youssef, R.F.; Spradling, K.; Yoon, R.; Dolan, B.; Chamberlin, J.; Okhunov, Z.; Clayman, R.; Landman, J. Applications of three-dimensional printing technology in urological practice. BJU Int. 2015, 116, 697-702. [CrossRef] [PubMed]

161. Dawood, A.; Marti, B.M.; Sauret-Jackson, V.; Darwood, A. 3D printing in dentistry. Br. Dent. J. 2015, 219, 521-529. [CrossRef]

162. Goyanes, A.; Scarpa, M.; Kamlow, M.; Gaisford, S.; Basit, A.W.; Orlu, M. Patient acceptability of 3D printed medicines. Int. J. Pharm. 2017, 530, 71-78. [CrossRef]

163. Liang, K.; Carmone, S.; Brambilla, D.; Leroux, J.-C. 3D printing of a wearable personalized oral delivery device: A first-in-human study. Sci. Adv. 2018, 4, eaat2544. [CrossRef]

164. Goyanes, A.; Madla, C.M.; Umerji, A.; Duran Piñeiro, G.; Giraldez Montero, J.M.; Lamas Diaz, M.J.; Gonzalez Barcia, M.; Taherali, F.; Sánchez-Pintos, P.; Couce, M.L.; et al. Automated therapy preparation of isoleucine formulations using 3D printing for the treatment of MSUD: First single-centre, prospective, crossover study in patients. Int. J. Pharm. 2019, 567, 118497. [CrossRef] [PubMed]

165. Trenfield, S.J.; Awad, A.; Goyanes, A.; Gaisford, S.; Basit, A.W. 3D Printing Pharmaceuticals: Drug Development to Frontline Care. Trends Pharmacol. Sci. 2018, 39, 440-451. [CrossRef]

166. Vakili, H.; Wickström, H.; Desai, D.; Preis, M.; Sandler, N. Application of a handheld NIR spectrometer in prediction of drug content in inkjet printed orodispersible formulations containing prednisolone and levothyroxine. Int. J. Pharm. 2017, 524, 414-423. [CrossRef]

167. Trenfield, S.J.; Goyanes, A.; Telford, R.; Wilsdon, D.; Rowland, M.; Gaisford, S.; Basit, A.W. 3D printed drug products: Nondestructive dose verification using a rapid point-and-shoot approach. Int. J. Pharm. 2018, 549, 283-292. [CrossRef]

168. Edinger, M.; Iftimi, L.-D.; Markl, D.; Al-Sharabi, M.; Bar-Shalom, D.; Rantanen, J.; Genina, N. Quantification of Inkjet-Printed Pharmaceuticals on Porous Substrates Using Raman Spectroscopy and Near-Infrared Spectroscopy. AAPS PharmSciTech 2019, 20, 1-10. [CrossRef]

169. Salzer, R.; Siesler, H.W. Infrared and Raman Spectroscopic Imaging; John Wiley \& Sons: Hoboken, NJ, USA, 2014. 
170. Edinger, M.; Bar-Shalom, D.; Rantanen, J.; Genina, N. Visualization and Non-Destructive Quantification of Inkjet-Printed Pharmaceuticals on Different Substrates Using Raman Spectroscopy and Raman Chemical Imaging. Pharm. Res. 2017, 34, 1023-1036. [CrossRef]

171. Trenfield, S.J.; Tan, H.X.; Awad, A.; Buanz, A.; Gaisford, S.; Basit, A.W.; Goyanes, A. Track-and-trace: Novel anti-counterfeit measures for 3D printed personalized drug products using smart material inks. Int. J. Pharm. 2019, 567, 118443. [CrossRef] [PubMed]

172. Wickström, H.; Nyman, J.O.; Indola, M.; Sundelin, H.; Kronberg, L.; Preis, M.; Rantanen, J.; Sandler, N. Colorimetry as Quality Control Tool for Individual Inkjet-Printed Pediatric Formulations. AAPS PharmSciTech 2016, 18, 293-302. [CrossRef] [PubMed]

173. Vakili, H.; Nyman, J.O.; Genina, N.; Preis, M.; Sandler, N. Application of a colorimetric technique in quality control for printed pediatric orodispersible drug delivery systems containing propranolol hydrochloride. Int. J. Pharm. 2016, 511, 606-618. [CrossRef] [PubMed] 